\title{
NA PRZEKÓR FORMATOWI. KILKA UWAG O POLSKIM DRAMACIE WSPÓŁCZESNYM
}

JACEK KOPCIŃSKI

\author{
Instytut Badań Literackich PAN \\ The Institute of Literary Research, \\ Polish Academy of Sciences in Warsaw \\ jacek.kopcinski@ibl.waw.pl \\ ORCID: 0000-0002-5347-9006
}

Jaki ma kształt, o czym opowiada i jak jest odbierana polska dramaturgia współczesna? Żeby sensownie odpowiedzieć na te pytania, trzeba najpierw zapytać o kontekst, w jakim powstaje ta pod wieloma względami wyjątkowa twórczość.

\section{KULTURA NOWOŚCI}

Zacznijmy od tego, że polskie sztuki współczesne inscenizuje się głównie w teatrach publicznych, których w Polsce jest ponad setka; drugie tyle to mniejsze teatry prywatne - na 38 milionów mieszkańców. Pracę z dramatopisarzami podejmuje jednak najwyżej dwadzieścia scen, przy czym nie jest to praca regularna, a po nowe sztuki sięgają zazwyczaj reżyserzy dopiero poszukujący swojego stylu. Na dodatek, gdy jakiś tytuł trafia na afisz, inne teatry już się nim nie interesują, bo w eventowej kulturze nowości, która zawitała do Polski, liczą się tylko prapremierowe inscenizacje ${ }^{1}$. Repertuar polskich teatrów publicznych opiera się w większości na różnego rodzaju adaptacjach: klasycznych tekstów dramatycznych (polskich i obcych), których nie chroni prawo autorskie, dzięki czemu można je dowolnie przekształcać; znanych powieści (dawnych, jak Nad Niemnem Orzeszkowej, i współczesnych, jak Widnokrąg Myśliwskiego, Moja walka Knausgårda czy Serotonina Houellebecqa); wreszcie popularnych scenariuszy filmowych (Pasoliniego, von Triera, ale także Feliksa Falka). Polski dramat współczesny jest w teatrze gościem rzadkim, a gdy się w nim pojawia, przyjmowany jest

1 Zob. T. Szlendak, Wielozmysłowa kultura iwentu. Skąd się wzięła, czym się objawia i jak w jej ramach ocenić dobra kultury?, „Kultura Współczesna” 2010, nr 4. 
raczej skromnie, na kameralnych scenach powierzanych młodym artystom, często debiutantom.

Minęły już czasy, kiedy utwory liczących się autorów brało na warsztat jednocześnie kilku ważnych reżyserów, a krytycy porównywali ze sobą ich interpretacje. Zmienił się także stosunek publiczności do twórczości dramatycznej. Już w latach 90. ubiegłego wieku, wraz z zasadniczą zmianą paradygmatu polskiej kultury w dobie ustrojowej transformacji, dramat przestał być lekturą obowiązkową wykształconych Polaków, którzy kiedyś najpierw zapoznawali się z tekstem, a potem sprawdzali, jak został on wystawiony w ich ulubionym teatrze. Obecnie dramatów raczej się nie czyta, paradoksalnie jednak - nadal się je publikuje. Polskie sztuki ukazują się w autorskich wyborach (np. ciekawa seria „Nasze dramaty” prezentująca twórczość takich autorów, jak: Małgorzata Sikorska-Miszczuk, Mariusz Bieliński, Tomasz Man czy Artur Pałyga). Powstają też antologie sztuk różnych pisarzy, a istniejący od sześćdziesięciu lat miesięcznik „Dialog” w każdym numerze drukuje dwa lub trzy nowe teksty. Ich lektura często okazuje się jednak za trudna dla nieprofesjonalnego czytelnika. Polski dramat już dawno odszedł od konwencji, z którymi większość czytelników i widzów zapoznawała się jeszcze w szkole średniej.

Mam na myśli awangardowy dramat lat 60. (w typie teatru absurdu), uprawiany przez Sławomira Mrożka czy Tadeusza Różewicza, i dramat realistyczny lat 70., zanurzony w polskiej historii lub podejmujący problemy społeczne, uprawiany przez Władysława Terleckiego czy Janusza Głowackiego. Sztuki tych autorów były bardzo dobrze znane, niektóre $\mathrm{z}$ nich trafiły nawet do kanonu lektur szkolnych i to one ukształtowały powszechne wyobrażenie o nowoczesnym dramacie (rozwijającym się w kierunku a to satyry społecznej czy filozoficznej, jak w sztukach Jarosława Abramowa-Newerlego czy Henryka Bardijewskiego, a to groteski historycznej, jak w sztukach Stanisława Grochowiaka czy Jarosława Marka Rymkiewicza, wreszcie - obyczajowej psychodramy, jak w utworach Ireneusza Iredyńskiego czy Tomasza Łubieńskiego). Dramaturgia współczesna, która od dawna rządzi się już zupełnie innymi zasadami - nie realizuje mianowicie zasad gatunkowych, rozluźnia lub łamie strukturę dramatyczną sztuk, odchodzi od konwencjonalnej

2 Informacje na jej temat można znaleźć na stronie www.akademicka.pl [dostęp 10.09.2020]. 
organizacji tekstu na rzecz amorficznego strumienia językowego - przez starszych czytelników postrzegana jest jako literacki półprodukt przeznaczony wyłącznie do scenicznej realizacji w progresywnych teatrach. Młodsi czytelnicy, nawykli do nowych, płynnych form komunikacyjnych: tekstowych, audialnych i medialnych, z którymi na co dzień obcują w internecie, łatwiej akceptują nowy kształt dramatu współczesnego. Bliższa jest im także nowa koncepcja lektury tekstu dramatycznego jako specyficznego performansu, indywidualnego, ale także zespołowego. Ostatnie lata to czas rozwoju tzw. czytań performatywnych, praktyki pozostającej na pograniczu inscenizacji i lektury tekstu dramatycznego, sprzyjającej uruchomieniu jego performatywnych i semantycznych zasobów bez angażowania całej machiny teatralnej.

\section{DRAMATOPISARZE I DRAMATURDZY}

Pisząc swoje utwory, współcześni autorzy reagują na oczekiwania reżyserów, którzy nie kryją niechęci do sztuk teatralnych w ogóle, a w szczególności tekstów, które cechuje wyrazisty styl, spójna fabuła i zamknięta kompozycja. Twierdzą, że tego rodzaju utwory ograniczają ich wyobraźnię, oczekują więc od autorów raczej surowego materiału przeznaczonego do dalszej obróbki niż skończonego dzieła. Jeszcze przed wybuchem epidemii uczestniczyłem w bardzo dobrze zrealizowanym czytaniu performatywnym jednej z polskich sztuk. Po jego zakończeniu reżyser czytania stwierdził, że jest ona zbyt dobrze napisana, by ją wystawić w teatrze, czytaj: pozostawia za mało miejsca na reżyserską inwencję. Dla większości inscenizatorów tekst stał się jedynie punktem wyjścia do kreacji własnych światów, zbudowanych raczej za pośrednictwem obrazów - często obrazów filmowych - a nie słów. $\mathrm{Na}$ dodatek, jak już wspomniałem, wcale nie musi być to tekst dramatyczny, czego najlepszym przykładem są spektakle Krystiana Lupy, który od lat adaptuje powieści wielkich modernistów (coraz chętniej także korzystając $z$ różnego rodzaju filmowych projekcji na scenie). Tendencję tę wzmacniają teatrolodzy, którzy walczą o autonomię teatru i zarazem własnej dziedziny wiedzy. W konsekwencji doszło do podważenia koncepcji teatru dramatycznego i sformułowania teorii teatru postdramatycznego - opartej na analizie dzieł znacznie bliższych performansowi (plastycznemu, muzycznemu, tanecznemu) niż spektaklowi teatralnemu, ale także na mocnym przeświadczeniu o konieczności osłabienia roli autora w teatrze. W tym roku minęło 
dwadzieścia lat od wydania głośnej książki Hansa-Thiesa Lehmanna Teatr postdramatyczny, która miała poważny wpływ na rozwój nowoczesnego teatru w Polsce. Idąc za myślą niemieckiego badacza - i przenosząc do Polski zasady działania niemieckich teatrów - zgodzono się ostatecznie na udział w kreacji teatralnej nie tyle dramatopisarza, ile dramaturga.

Za tymi dwoma, mimo iż podobnymi do siebie, słowami kryją się jednak dwie zupełnie różne postawy artystyczne. Dramatopisarz tworzy oryginalny tekst literacki możliwy do uruchomienia za pośrednictwem różnych mediów - teatru, ale także radia, telewizji, internetu. Natomiast dramaturg zajmuje się adaptacją tekstów już napisanych, najczęściej niedramatycznych, względnie nadaje dramatyczną strukturę wypowiedziom zaimprowizowanym na scenie przez aktorów. W obu przypadkach jego rola jest podrzędna względem wizji autora adaptowanego dzieła lub wobec reżyserskiej wizji spektaklu. Oczywiście podejmując współpracę z dramatopisarzem, reżyser niejednokrotnie negocjuje zmiany w tekście, jednak na całkowite „przepisanie” utworu autorzy zwykle się nie zgadzają. Żeby uniknąć takich kuriozalnych praktyk, a jednocześnie zaistnieć w teatrze, dramatopisarze przyjmują trzy strategie. Po pierwsze, piszą teksty kolażowe, hybrydyczne, często pozbawione podstawowych wyróżników dramatycznych, jak choćby imion postaci. Teksty takie łatwo bowiem poddają się rozmaitym zabiegom inscenizacyjnym. Po drugie, piszą teksty na zamówienie i na określony temat, wychodząc naprzeciw oczekiwaniom reżysera czy dyrektora teatru. Po trzecie, autorzy sztuk sprzymierzają się na stałe z konkretnymi reżyserami. W Polsce funkcjonuje kilka takich ciekawych duetów, przykładem są Monika Strzępka - reżyserka i Paweł Demirski - autor czy Jolanta Janiczak - autorka i Wiktor Rubin - reżyser. Część zdolnych autorów pełni też w niektórych teatrach funkcje kierowników literackich lub właśnie dramaturgów, nie tracąc przy tym szansy pracy nad własnymi utworami, które jednak rzadko są wystawiane. W takiej podwójnej czy nawet potrójnej roli występują dziś Anna Wakulik (Teatr Dramatyczny w Warszawie) czy Artur Pałyga (Teatr Śląski im. Stanisława Wyspiańskiego w Katowicach).

\section{TEATR RADIOWY I TELEWIZYJNY}

Nawet najbardziej awangardowe teksty dramatyczne takich autorów, jak: Tomasz Man, Zyta Rudzka czy Mariusz Bieliński od lat realizuje Teatr 
Polskiego Radia, gdzie działają trzy odrębne pasma teatralne $e^{3}$. Radio stało się prawdziwym domem polskiego dramatu, a współczesne audycje radiowe coraz częściej czerpią z estetyki awangardowego sound designu i korzystają z wyrafinowanej technologii dolby surround ${ }^{4}$. Niestety, większość krytyków radia nie słucha, słuchowiska pozostają więc bez recenzji, mimo że krąg odbiorców audycji radiowych jest naprawdę szeroki, a w promocje polskiego słuchowiska włączają się nawet tak wyspecjalizowane placówki, jak Instytut Teatralny w Warszawie (cykl maratonów „Nasłuchiwanie”, próba stworzenia Studia Teatralnych Form Eksperymentalnych wraz z Polskim Radiem). Z dramatopisarzami współpracuje także teatr telewizyjny, który w Polsce rozwija się dwutorowo: w telewizji publicznej i w studiach jednej z państwowych wytwórni filmowych (WFDiF). Powstająca tam seria "Teatroteka” liczy już ponad czterdzieści spektakli, których reżyserami są młodzi, zdolni artyści, swobodnie operujący zarówno teatralnymi, jak i filmowymi środkami wyrazu. Niektórzy z dramatopisarzy właśnie dzięki nim doczekali się najlepszych realizacji swoich sztuk. Ponieważ niektóre przedstawienia "Teatroteki” są dostępne w sieci, chciałbym wymienić te najbardziej znaczące: Walizka Małgorzaty Sikorskiej-Miszczuk, Nad Mariusza Bielińskiego, Gardenia Elżbiety Chowaniec, Wasza Wysokość Anny Wakulik, Zakład doświadczalny Solidarność Szymona Bogacza, Żyd Artura Pałygi, Wariat Rafała Wojasińskiego, Spalenie Joanny Magdaleny Miecznickiej, Słabi Magdaleny Drab. Na pierwszy rzut oka są one do siebie podobne. Nie tylko dlatego, że powstają w tej samej hali zdjęciowej, w umownej scenografii, z wykorzystaniem pokrewnych środków filmowych. Także dlatego, że reżyserują je artyści należący do tego samego pokolenia. Jeżeli jednak lepiej przyjrzymy się tym przedstawieniom, szybko odkryjemy, że każdy z jego realizatorów musiał znaleźć własny, odrębny język dla wystawienia wybranej przez siebie sztuki.

\section{POZA KONWENCJAMI}

Współczesna polska dramaturgia nie proponuje bowiem żadnego wspólnego wzorca inscenizacyjnego. Owszem, dominują w niej środki typowe

3 Zob. Świat (w) polskiej dramaturgii najnowszej, cz. 1: W lekturze i na scenie, cz. 2: W radiu, red. J. Kopciński, Warszawa 2016.

4 Zob. J. Łastowiecki, Specyfika odbioru słuchowiska radiowego, Toruń 2019.

5 Zob. www.teatroteka.com.pl/spektakle [dostęp 10.09.2020]. 
dla teatru postdramatycznego, m.in. różne formy narracji wpisanej w tekst utworu. Jednak to, co jest dla niej najbardziej charakterystyczne, polega na ucieczce od wszelkiej konwencji i otwarciu na wielość interpretacji. Tekst pozbawiony wyrazistej struktury zdaje się ewokować równie płynną i chaotyczną rzeczywistość, w istocie jednak chodzi o coś innego. Świat w polskiej dramaturgii podlega częstym transformacjom o metaforycznym lub symbolicznym charakterze. Umarli spotykają się w nim z żywymi, żywi ulegają sile swoich wspomnień lub wyobraźni i swobodnie przekraczają granice czasu i przestrzeni. Choć polskie sztuki powstają w zupełnie nowym kontekście historycznym, kulturowym i społecznym, obecny jest w nich pierwiastek XIX-wiecznego dramatu romantycznego, który przed odbiorcami otwierał przestrzeń metafizyczną i sakralną.

To właśnie za sprawą romantycznych poetów i dramatopisarzy - Adama Mickiewicza, Juliusza Słowackiego, Zygmunta Krasińskiego - kultura polska jest w swojej istocie kulturą dramatyczną, a stworzeni przez nich bohaterowie - Konrad, Kordian, hrabia Henryk - do dziś traktowani są jak bohaterowie narodowi. Polski dramat najnowszy nie wykreował tego typu znaczących figur zbiorowej wyobraźni. Wynika to oczywiście z charakteru nowoczesnej kultury, która głosi kryzys, a nawet rozpad silnego podmiotu, ale także samego teatru, który bardzo się zdemokratyzował. Jeśli na scenie zjawia się dziś „bohater naszych czasów”, to jest nim raczej ktoś przeciętny, a nie wyjątkowy, everyman, a nie heros. Zarazem jednak polscy autorzy chętnie dekonstruują biografie ważnych postaci historycznych, jakby tęsknili za ich autorytetem, a jednocześnie nie potrafili go przyjąć. Przykładem są dwie sztuki Małgorzaty Sikorskiej-Miszczuk: Popiełuszko. Czarna msza i Kuroń. Pasja według świętego Jacka. Nieufność, dystans, ironia, rozczarowanie, bunt to cechy szczególne polskiej dramaturgii. Z czego one wynikają?

\section{KONKURSY I SERIALE}

Zawód dramatopisarza nie jest w Polsce zawodem dochodowym, dlatego autorzy muszą szukać innego zatrudnienia, co nie pozostaje bez wpływu na ich twórczość. Mam na myśli przede wszystkim pracę w telewizji. Pamiętam spotkanie z Przemysławem Pilarskim, jednym z bardziej znanych autorów młodszego pokolenia, który tekstem Tata wiesza się w lesie wygrał konkurs na dramat kameralny organizowany w warszawskim Teatrze Młyn. Oprócz nagrody pieniężnej laureat mógł liczyć na performatywne czytanie swojej 
sztuki w Instytucie Teatralnym oraz rozmowę z jurorami. Na pytanie, dlaczego jego bohater - nastolatek - od początku do końca pozostaje taki sam, mimo rozwijającej się relacji z dziewczyną poznaną na czacie, autor odpowiedział: „Przemianę bohatera to ja ćwiczę w telewizji, pisząc kolejne odcinki serialu; kiedy siadam do swojej własnej sztuki, próbuję zapomnieć o tej konwencji”.

Odpowiedź autora była szczera i bardzo pouczająca. W Polsce rzeczywiście wielu dramatopisarzy zarabia na życie, wypełniając dialogami serialowe „drabinki”. Niektórzy z nich robią to sprawnie i wydajnie, prowadząc na co dzień życie nieźle sytuowanej klasy średniej. Praca w telewizyjnym tasiemcu, zwanym w Polsce „telenowelą” (nie należy go mylić z krótkimi, niekiedy bardzo a mbitnymi artystycznie serialami HBO czy Netflixa), nie daje im jednak artystycznej satysfakcji. Szukają więc innego sposobu skomunikowania się z odbiorcami i zazwyczaj wybierają dramat, który traktują jako narzędzie dekonstrukcji „mieszczańskich” estetyk i dyskursów, na których opiera się konwencja telenoweli. Oczywiście istnieje wiele innych czynników, które wpływają na kształt polskiej dramaturgii współczesnej, takich jak teoria i praktyka teatru postdramatycznego, zwrot performatywny w literaturze i teatrze czy rozwój technologii i nowych mediów, które weszły do teatru. Liczy się także dominacja paradygmatu sztuki krytycznej, która każe polskim autorom reagować na agendę globalnych problemów: społecznych, ekonomicznych czy ekologicznych. W zderzeniu z tak szeroką i poważną problematyką - naukową, artystyczną, polityczną - indywidualne przygody polskich dramatopisarzy z mało ambitnym telewizyjnym formatem wydają się mało istotne, a jednak nie warto ich lekceważyć.

Telewizja nadal pozostaje najważniejszym środkiem masowej komunikacji, a jej wpływ na opinię publiczną jest w Polsce ogromny. Natomiast telenowele: Barwy szczęścia, M jak miłość, Na wspólnej, Na dobre i na złe, Pierwsza miłość, Leśniczówka i wiele innych, a także inne popularne programy (muzyczne, kulinarne, motoryzacyjne, modowe) kształtują zbiorową wyobraźnię Polaków w stopniu znacznie większym niż literatura, teatr czy film razem wzięte. Czynią to oczywiście w zgodzie ze świetnie sprawdzonym, komercyjnym schematem, który służy przede wszystkim rozrywce, a nie poznaniu. Mierząc się z polską rzeczy wistością w jej rozmaitych wymiarach i aspektach, dramatopisarze muszą więc najpierw skruszyć jej wyidealizowany, a zarazem bardzo uproszczony, konwencjonalny 
i stereotypowy obraz wytwarzany w studiach telewizyjnych. A ponieważ sami go współtworzą jako serialowi scenarzyści, ich odpowiedź bywa bardzo radykalna, bo podszyta poczuciem winy za formatowanie umysłów milionów Polaków. Podobny rodzaj zawodowej schizofrenii przeżywa dziś zresztą wielu innych artystów, zwłaszcza popularnych aktorów, którzy rano kręcą kolejne odcinki telewizyjnego tasiemca, a wieczorem uprawiają sztukę krytyczną w progresywnych teatrach Warszawy, Krakowa czy Poznania.

\section{FORMAT SERIALOWY}

Sprawdziłem, na czym polega format, przed którym bronił się nasz dramatopisarz. Każdy odcinek jego serialu składa się z kilkunastu scen ukazujących na zmianę trzy lub cztery wątki fabularne rozgrywające się w kilku miejscach wśród bohaterów tworzących stałe pary lub uczestniczących w życiu małych wspólnot (rodzinnych, sąsiedzkich, szkolnych, zawodowych). Każdy wątek ma swoje zawiązanie i swoją kulminację, w ciągu trzydziestu minut każdy z bohaterów dowiaduje się o czymś ważnym lub podejmuje jakąś istotną decyzję (moment ten zwiastuje stały motyw muzyczny). W świecie serialu nie ma życiowych przestojów. Bohaterowie stają przed mniejszymi lub większymi zadaniami i je podejmują lub nie, w zależności od swojego charakteru i okoliczności ich życia. Widzowie wiedzą więcej od postaci i lepiej rozumieją ich sytuację, bo znają wszystkie zaplatające się wątki. Satysfakcji dostarcza im więc obserwowanie tego, w jaki sposób poszczególne osoby radzą sobie ze swoimi problemami, a także ocena ich postępowania. Nie jest to trudne, bo w serialu zawsze wiadomo, kto czyni dobrze, a kto źle, kto kłamie, a kto mówi prawdę, czyje intencje są czyste moralnie, a czyje nie.

Świat ukazany w filmie różni się w zależności od społecznego statusu bohaterów, ale serialowi scenarzyści unikają ideologicznych deklaracji i odniesień do parlamentarnych sporów, komentowanych w innych programach telewizyjnych. Koncentrują się na życiowych perypetiach postaci, które nie wykraczają poza doświadczenie przeciętnego odbiorcy. Bohaterowie nawet w ekstremalnych sytuacjach, takich jak choroba psychiczna czy śmierć bliskiej osoby, zachowują się w sposób określony przez telewizyjne decorum. Owszem, przeżywają swoje różne kryzysy: małżeńskie, zawodowe, także wewnętrzne, ale ich osobowość nie podlega destrukcji. Nawet w najtrudniejszych momentach pozostają sobą, zgodnie ze sformatowanym charakterem, a przeżycia, które zmieniają ich świadomość, komunikują w typowy dla 
siebie sposób. Ich zadaniem jest zmienić się na lepsze, doświadczając większych lub mniejszych trudności. Prędzej czy później każdy z serialowych bohaterów powie: kiedyś byłem innym człowiekiem!

Serialowy świat jest spójny etycznie i ontologicznie, a narzędziem jego prezentacji pozostaje konwencja realistyczna oparta na społecznej normie, która może być rozszerzana, ale nie podważana. Realizm ten na poziomie estetycznym zakłada logikę kompozycyjną, prawdopodobieństwo i jasność komunikacyjną. Niczego takiego nie znajdziemy w nowym polskim dramacie, który na różne sposoby dekonstruuje wszystkie te założenia.

\section{DRAMATYCZNA DEKONSTRUKCJA}

Dramat jest ze swojej istoty wypowiedzią nienormatywną, począwszy od języka, przez temat, strukturę fabularną, bohaterów, po budowany w utworze obraz rzeczywistości. W reakcjach serialowych bohaterów nie ma miejsca na jakąkolwiek transgresję: umysłową, psychiczną, cielesną, seksualną czy językową, natomiast dramat właśnie na niej opiera swój przekaz. Pierwszy, podstawowy komunikat, jaki szyfrują polscy autorzy w swoich sztukach, brzmi: świat wygląda inaczej, niż to widzicie (w serialach)! Właśnie dlatego tak często opowiadają one o przemocy w rodzinie, samotności porzuconych dzieci, chorobie najbliższych, depresji poporodowej, zabójstwie lub śmierci ojca, żałobie po znienawidzonej matce, zabójstwie dokonanym przez ukochanego syna, niesprawiedliwym wyroku, niszczącym bezrobociu, kryzysie wiary, pedofilii, aborcji, doświadczeniu transpłciowości i wojennej traumie odziedziczonej po rodzicach, kłamstwie politycznym, medialnej manipulacji czy wypartej zbrodni na sąsiadach innej narodowości ${ }^{6}$. By się o tym przekonać, wystarczy zajrzeć do drugiego tomu antologii polskiego dramatu po 1989 roku Transformacja i przeczytać takie sztuki, jak: Trash story Magdaleny Fertacz, Cukier Stanik Zyty Rudzkiej, Między nami dobrze jest Doroty Masłowskiej, Łucja i jej dzieci Marka Pruchniewskiego czy Nad Mariusza Bielińskiego, albo dokładnie przejrzeć archiwa Gdyńskiej Nagrody Dramaturgicznej, gdzie dostępne są takie sztuki, jak: Nasza klasa Tadeusza Słobodzianka, Ciała obce Julii Holewińskiej, Burmistrz Małgorzaty Sikorskiej-Miszczuk, Zgaga Ewy Madeyskiej, Słabi Magdaleny Drab czy

6 Zob. P. Dobrowolski, Teatr i polityka. Dyskursy polityczne w polskiej dramaturgii współczesnej, Poznań 2019. 
Wracaj Przemysława Pilarskiego. Wspólnym założeniem wszystkich tych tak różnych dramatów jest zmiana „optyki” naszego skonwencjonalizowanego spojrzenia na rzeczywistość, zanurzenie w „kulisy” teatru życia codziennego, zejście do psychicznego „podziemia” naszych doświadczeń i reakcji, indywidualnych i zbiorowych.

Ale to tylko pierwszy krok, ponieważ zasadą pracy dramatopisarza jest rewizja stereotypowych opinii na każdy z wymienionych wyżej tematów. Zakres doświadczeń każdego z nas jest dość wąski - tłumaczą dramatopisarze - natomiast zakres naszych przeświadczeń o innych ludziach pozostaje bardzo szeroki. Potrafimy osądzić cały świat, ale nie zastanawiamy się, dlaczego właśnie tak myślimy. Dramat ma nam to uświadomić: wytrącić z myślowych przyzwyczajeń, zmienić pespektywę spojrzenia na sprawy, które uznawaliśmy za oczywiste, skomplikować ich utrwalony obraz, odsłonić sprzeczności, skonfrontować z tym, co niechciane, zapomniane, wyparte. Nie tak jednak, jak czyni to reportaż, często inspirujący polskich autorów. Lektura sztuki lub też jej odbiór teatralny w o wiele większym stopniu angażuje odbiorców w życie ludzi, którzy w dramacie odzywają się przecież własnymi głosami, a w teatrze wychodzą nam na spotkanie. Dramat, jak żaden inny rodzaj literacki, stanowi partyturę bardzo trudnych doświadczeń, przeznaczoną do bardzo indywidualnego „wykonania”: aktywnego odbioru, zrozumienia, przeżycia. Polscy autorzy dobrze o tym wiedzą i umiejętnie ożywiają performatywny wymiar słowa dramatycznego. Drugi komunikat zaszyfrowany w polskich sztukach współczesnych brzmi więc tak: jest zupełnie inaczej, niż wam się wydaje!

\section{POLSKA SPECYFIKA}

Rewizja stereotypów to przede wszystkim kwestia języka, który w dramacie z zasady zaprzecza skonwencjonalizowanym formom ekspresji i komunikacji. Można powiedzieć, że autorzy oddają głos nie tyle swoim bohaterom, ile ich myślom, emocjom, wspomnieniom, nieuświadamianym pragnieniom, które „odzywają się” w niespodziewanych momentach i zaskakują nie tylko odbiorców. Trzeci komunikat zaszyfrowany w polskich sztukach brzmi więc: mówicie nie to, co chcecie powiedzieć, język zdradza waszą mentalność! Oczywiście język odpowiednio spreparowany, poddany stylizacyjnym zabiegom, nieprzezroczysty. Choć polscy pisarze posługują się poetyką znaną także w innych dramaturgiach: niemieckich, angielskich, 
rosyjskich, to świadomość, którą ujawniają, jest lokalna. Dialogi i monologi bohaterów polskich sztuk demaskują sposób myślenia ludzi urodzonych nad Wisłą, ochrzczonych w katolickich świątyniach, wykształconych na polskich elementarzach. Do wszystkich wymienionych wcześniej tematów należy więc dodać krótką formułkę „po polsku”. Nawet bowiem choroba, a więc doświadczenie z pozoru uniwersalne, wywołuje $\mathrm{w}$ bohaterach polskich sztuk inne myśli i reakcje. Podobnie ojcostwo czy macierzyństwo, kolejne $\mathrm{z}$ uniwersalnych tematów, które w polskim dramacie realizują się inaczej niż w sztukach obcych. Czy to przypadek, że dwaj zupełnie różni polscy autorzy - Artur Pałyga i Mariusz Bieliński - do dramatów ukazujących trudne relacje między ojcem i synem wprowadzili wątki i symbole religijne (obaj też zatytułowali swoje sztuki Ojcze nasz)? A inny autor, Marek Pruchniewski, oddając głos sparaliżowanej bohaterce, w dramacie o znaczącym tytule Ciało moje zapytał na koniec o teologiczny wymiar doświadczenia choroby? Odniesienia do liturgii czy katolickiej hagiografii w dramatach SikorskiejMiszczuk też nie są przypadkowe. Choć katolicyzm w Polsce coraz częściej ma wymiar kulturowy, a nie religijny, nadal stanowi fundament polskiej mentalności i hermeneutyczną przestrzeń analizy zbiorowej wyobraźni Polaków. Nowa dramaturgia testuje naszą religijność i niereligijność, naszą zmieniającą się obyczajowość, złożony stosunek do historii, tradycji i nowoczesności. Jest specyficznym „kodem dostępu” do polskiej świadomości, a zwłaszcza nieświadomości, otwierającym wiele niewidocznych drzwi, które czasami chciałoby się jak najszybciej zatrzasnąć7.

Na szczęście po lekturze ważnych polskich sztuk nie jest to już możliwe. Czwarty zaszyfrowany w nich komunikat ostrzega bowiem przed obojętnością: musicie zmierzyć się ze sobą i wziąć odpowiedzialność za świat, który właśnie poznaliście! Jeżeli kultura seriali usypia swoich odbiorców, polska kultura dramatyczna budzi ich z masowego letargu. A przynajmniej usiłuje to robić. Mimo że telewizyjne scenariusze i sztuki teatralne piszą często ci sami autorzy, krąg ich odbiorców właściwie się nie przenika. Polska dramaturgia współczesna jest oryginalna, transgresyjna, fantazmatyczna i bezkompromisowa, ale przez to dość ekskluzywna. Tylko niektórym autorom udało się dotrzeć do szerszej publiczności, a pomogło im w tym radio oraz

7 Więcej na ten temat pisałem w: J. Kopciński, Wybudzanie. Dramat polski. Interpretacje, Warszawa 2018. 
Teatr Telewizji, w którym nadal liczy się tradycyjnie skonstruowany dialog, intryga, akcja i wyrazisty bohater. Sztuki takie piszą dziś Wojciech Tomczyk, autor świetnej Norymbergi, która podejmuje temat zaniechanej w Polsce dekomunizacji, czy Marek Modzelewski, który w swoim najnowszym Wstydzie demaskuje klasową mentalność współczesnych Polaków. Dramatopisarze bardziej radykalni w swoich estetycznych wyborach wytykają im zbytni tradycjonalizm, ale nie mogą zarzucić ich sztukom trywialności. Nawet zachowując klasyczne reguły swojego gatunku, dramat może wstrząsać i dawać do myślenia.

\section{Bibliografia}

Piotr Dobrowolski, Teatr i polityka. Dyskursy polityczne w polskiej dramaturgii wspótczesnej, Poznańskie Studia Polonistyczne, Poznań 2019.

Jacek Kopciński, Wybudzanie. Dramat polski. Interpretacje, Instytut Badań Literackich PAN, Warszawa 2018.

Janusz Łastowiecki, Specyfika odbioru stuchowiska radiowego, Wydawnictwo Adam Marszałek, Toruń 2019.

Tomasz Szlendak, Wielozmysłowa kultura iwentu. Skąd się wzięła, czym się objawia i jak w jej ramach ocenić dobra kultury?, „Kultura Współczesna” 2010, nr 4. Świat (w) polskiej dramaturgii najnowszej, cz. 1: W lekturze i na scenie, cz. 2: W radiu, red. J. Kopciński, Instytut Badań Literackich PAN, Warszawa 2016.

\section{Źródła internetowe}

www.akademicka.pl

www.teatroteka.com.pl/spektakle

\section{In Spite of the Format. A Few Remarks on Polish Contemporary Drama}

The author of the essay reflects on the original shape of Polish contemporary dramaturgy, which ostentatiously breaks the known genre rules at the level of language, style, composition, construction of the protagonist and the presented world. He lists many reasons for this, focusing on the surprising relationship between contemporary drama and the format of popular television series produced in soap opera style. This is a negative relation - the authors who write TV scripts on a daily basis ostentatiously deny the use of the series' 
formats in their dramatic texts. Thus, in Polish contemporary culture, we observe an interesting tension with the conventionalized, yet extremely popular formula of the series and the very avant-garde, and at the same time exclusive poetics of many Polish theater plays. This tension concerns both aesthetic and worldview. While the series propose a rather conservative vision of the world, contemporary plays eagerly revise it from a liberal or leftist perspective. The negative reference to the poetics of the drama series allows us to capture many of its characteristic features, such as hybridity, transgression and criticality.

Keywords: Polish contemporary drama, series, theater, television format 